\title{
AYLAK ADAM VE YABANCI ROMANINDA YABANCILAŞMA
}

\author{
ALIENATION IN $A Y L A K A D A M$ AND THE OUTSIDER
}

\section{ОТЧУЖДЁННОСТЬ В РОМАНАХ “ПРАЗДНОШАТАЮЩИИСЯ ЧЕЛОВЕК” И “ЧУЖОЙ"'1}

Hande Bağcı

\section{Öz}

Yabancılaşma, bireysel ve toplumsal sürecin birlikte ortaya çıkardığı psikolojik bir sorundur. İnsanın öz benliği ile varlığının çelişmesi sonucu bir öteki ortaya çıkar ve yabancılaşmanın temelinde de bu yatmaktadır. İnsan özünün tanımlanmasındaki zorluklar yabancılaşma kavramının ortaya çıkmasındaki temel sebeplerdendir. Bu tarihsel süreci içerisinde bir hayli derinlik kazanan ve günümüz çağdaş toplum insanında nirvanasına ulaşan bir hastalık olgusu olarak karşımıza çıkmaktadır.

İnsanın özü ile varlığının bu çelişik hali sonucunda ortaya çıkan ve bir öteki benlik ortaya çıkaran yabancılaşma kavramı insan psikolojisinin en karmaşık fakat en yaygın hastalığı olarak var olmuştur. Bu, edebi eserlerde de usta kalemlerin sıklıkla kullandığ 1 bir olgu olarak mevcuttur. Bu çalışmamızda da yabancılaşma olgusunun kavramsal olarak ele alınmasının yanı sıra Yabancı ve Aylak Adam romanlarındaki dinamik bir şekilde ele alınan süreciyle karşılaştırmalı bir incelemesi yapılacaktır.

Anahtar Sözcükler: Yabancılaşma, İnsan Özü, Toplum, Yabanc1, Aylak Adam

\section{АННОТАЦИЯ}

Отчужденнность, это общий психологический итог индивидуальных и социальных процессов. При противостоянии человеческого эго и эго существования, рождается чужой и входит в основу отчужденности. Основными причинами появления симптомов отчужденности являются трудности при определении человеком своей сущности. На протяжении исторического процесса, в современном человеке появляются довольно глубокие психические заболевания, достигающие до нирваны индивида.

Концепция отчужденности как итога противостояния человеческого эго с его существования, стала рссматриватся в качестве распространённого и комплексного заболевания. Она часто используется в произведениях известных писателей. В статье, через сопоставление, исследуется динамика отчуждённости в романах “Праздношатающиися человек” и “Чужой”.

1 . DOI : 10.17498/kdeniz.852 
Ключевые слова: отчужденность, человеческое эго, общество, чужой, праздношатающиися человек.

\section{Yabancılaşma Kavramı ve Tarihsel Gelişimi}

Kapitalizm ile birlikte emek değer algısının değişmesi, emeğin üründen ayrılması ve maddenin insan yaşamındaki öneminin hızlı tırmanışına paralel olarak ortaya çıkan yalnızlık, yabancılaşmayı doğurmuştur. Yabancılaşma kavramı kökeni bakımından peygamberlerin düşünceleri ve daha da ilerisi olarak putperestlik anlayışında da bulunmaktadır. Tek tanrıcılık ile çoktanrıcılık arasındaki ayrım bu süreç içerisinde yabancılaşma olgusunun oluşumuyla gerçekleşmiştir. Birey önce kendi yaptığı putlara taparken sonrasında başka bir özneye, kendisinden ayrı ve yüce bir varlığa tapmayı öğrenir. Kendi gücü ve yeteneklerinin üzerine çıkar, bir nevi üstün bir varlığı arar.

Yabancılaşma olgusuna somut bir boyut kazandırarak ortaya atan ve bu olguya dikkat çeken iki büyük düşünür Marx ve Hegel'dir. Dünyanın içerisinde barındırdığı nesne, doğa ve insanıyla yine insana yabancılaşmış olduğu düşüncesi onlara göre bu olgunun temelidir; “...̈̈yleyse yabancılaşma, Marx'a göre insanın hastalı̆̆ıdır." (Fromm, 2015:57) . Marx, öncelikle yabancılaşmış emek kavramını sosyo-ekonomik düzeyde iktisadi alanın kapitalist evrimindeki yeriyle ele alır ve sonrasında insanın öncelikle kendisine sonra başka insanlara ve doğaya olan yabancılaşmasını inceler. Ona göre yabancılaşma insansal değerleri yozlaştırmaktadır; "Marx'ın görüşüne göre kapitalizmde her insan, bir başkasında onu yeni bir özveriye zorlamak, yeni bir bağımlılık içine sokmak ve yeni bir haz türü ile kandırıp böylece ekonomik bakımdan yıkmak için yeni bir gereksinme yaratma konusu üstünde durur. Herkes, başkaları üstünde yabancı bir güç kurmak ister." (Fromm, 2015:59). Doğuştan gelen toplumsal direktifler, beklentiler ve kısaca dış faktörlerden gelen kabul görmüş hazır bilgilerle oluşan benlik, bireyin kendilik, benlik oluşumunda bir hayli etkilidir ve bireyin ben olgusunu yaratımı toplumsal etkiler dahilinde özgünlükten uzak bir biçimde insanın insan üzerindeki etkilerine örnek teşkil edecek biçimde gerçekleşir. Tüketim, insanın insan üzerinde yabancı bir güç kurarak yönlendirmesiyle ortaya çıkar. Ortaya çıkan ‘öteki’ ile ‘ben’i arasında yabancılaşan bireyler toplumsal düzende var olur.

“Yabancılaşma kuramı, Marx'ın kapitalist üretimin insanoğlunun fiziksel ve akli durumu ile bir parçası olduğu toplumsal süreç üzerindeki yıkıcı etkisini gösterdiği entelektüel yapıdır. Bu kuramda Marx, eylemde bulunan bireyi merkeze alır. Aslında bu kuram Marx'ın, yaşayan insanları, onların yaşam koşullarını(etkileşimlerini kavramak için kullanılan formlar gurubu) ve bu koşullar altında sürdürdükleri yaşamı (bu formların içini dolduran içerik) anlama yöntemidir." (Ollman, 2008:213). Bertell Olmann'ın ele aldığ1 başlıklarla Marx, yabancılaşmayı dört ilişkiye ayırarak inceler: "Insanın üretici etkinliğiyle ilişkisi”, "Insanın ürünüyle ilişkisi", "İnsanın diğer insanlarla ilişkisi” ve "İnsanın türüyle ilişkisi".

Hegel'e göre mutlak idea, doğayla bir bütün olarak evreni oluşturur. Bu diyalektik süreç yabancılaşarak gerçekleşir. İnsan bu diyalektik süreçte son duraktır. İnsan ruhu ve bilinci bu saltık düşünceyi yeniden kendisine kavuşturmak adına bir araç olarak kullanılır. Fakat bu süreçte insan kendi bilincinin farkına vararak bir anlamda yabancılaşır ve kendi varlığını oluşturur. Hegel bu görüşleriyle yabancılaşmayı diyalektik sürecin bir aşaması olarak görür. Marx, diyalektik sürecin bir aşaması olan yabancılaşmayı evrensel bir ilke boyutunda ele almamaktadır. Hayatın insan yaşamı üzerindeki somut koşullarını incelemiş yabancılaşma olgusunu somut etkileriyle ele almıştır; "Hegel'den farklı olarak, yaşadığl 
çă̆l, uzaklaşmanın yerini uzlaşmaya ve sükûnete bıraktı̆̆l, insanoğlunun kendi kendisiyle bir iç barışa vardıktan sonra nihayet kendinegeldiği bir dönem olarak görmüyordu." (Pappenheim, 2002:75). Farklı bir bakış açısıyla ele alıyor; "yaşamın, insanın yabancılaşmasına yol açtığına inandı̆̆ fiili ve somut koşullarıyla ilgileniyordu." (Pappenheim, 2002:75). Kapitalist üretim sisteminde somutlaştırılan yabancılaşma olgusu Marx tarafından oluşturulur. Hegel'in temelini oluşturduğu emeğin yabancılaşması Marx ile sistemli bir şekilde incelenir.

Kierkegaard, umutsuzluğun ölümcül bir hastalık olduğunu anlattığı eserinde umutsuz insanın, aslında tinin ve Ben'in üç farklı görünümlü umutsuzluğunu ele alır ve bu kendisine yabancılaşan insanın yansımalarıdır; "Bir ben olduğunun farkında olmayan umutsuz kişi (Bu gerçek bir umutsuzluk değildir); Kendisi olmak istemeyen umutsuz kişi ve kendisi olmak isteyen umutsuz kişi."(Kierkegaard, 2014:21). Genel anlamda ise, "Insan, sonsuzluk ile sonlunun, geçici ile kalıcının, özgürlük ile zorunluluğun bir sentezidir."(Kierkegaard, 2014:21) diyerek insanın ikilemlerden, zıtlıklardan oluşan varoluş sorununa değinir. Umutsuzluğun varlığı onun tanımında insanı kendisi olmaktan uzaklaştıran sistemler dahilindedir. Üç başlık altında varlığını anlattığı umutsuzluk, insanın kendisine yabancılaşmasının hem temeli hem sonucu olarak yerini almaktadır. O tamamen yok olduğunda da Ben'in kendine yönelerek, kendi olmayı öğrenip kendi içselliğinde kendisini var eden gücün farkına varacağına inanır. Kierkegaard, toplumun insanı kendisinden kopardığını ve bu yolda benliğine yabancılaştı̆̆ını savunur. Onun temel aldığı şey öznel düşüncedir. Bireyin öznel düşünce ile içsel ve insani düşüncelerine sahip olacağını, toplumun sürüklediği bir birey olmaktan uzaklaşacağını savunur. Marx'ın öncüllediği nesnellik, Kierkegaard'ta umutsuzluk kavramı ile birlikte öznelliğe dönüşür; “Umutsuzluk tamamen yok olduğunda, ben'in durumunu betimleyen formül şudur: Ben, kendine yönelerek, kendi olmak isteyerek, kendi saydamlı̆̆ içinde onu ortaya koyan gücün içine dalar."(Kierkegaard, 2014:23).

Kierkegaard'ın öncüllediği tanrı korkusu birçok düşünürde farklı biçimlerde ortaya çıkar; "Tanrıtanımaz varoluşçulardan Heidegger, Kierkegaard'dan farklı olarak tanrı korkusu yerine ölüm korkusunu koyar, yabancllaşmayı insanın ezeli ve ebedi kaderi gibi görür. Bununla birlikte insanı, kendi iç benliğinin yasalarına uymayan ve yönlendirilen bir varlı olarak tanımlar."(Tabanoğlu, 2015:2). Freud ise felsefi bir kuram olarak kapsamlı bir biçimde ele almasa da oluşturduğu Psikanalitik kuramla yabancılaşma olgusuna bireysel bir derinlik katmıştır. Ruh hastalarının kendileri üzerinde çözümlemeler yapan doktorlara aşık olmak, nefret etmek yahut korkmak gibi şiddetli duygular beslediğini gözlemleyen Freud hastaların çocukken anne ya da babalarına karşı hissettikleri duyguları aktardıklarını, onların anne ve babalarıymış gibi iletişim kurduklarını keşfetmiştir.

Freud'un toplumsal nevrozları ile Marx'ın bu konudaki düşünceleri arasında ayrımlar görülür; "Marx, insanı toplum tarafindan biçimlendirilmiş bir varlık olarak gördüğü için bozuklukların köklerini toplumsal düzenin belirli niteliklerinde görür. Freud iseinsanı öncelikle aile içindeki deneylerinin biçimlendirdiğine inanır. Ailenin, toplumun yalnızca bir temsilcisi ve öğesi olmasl olgusuna pek az önem verir." (Fromm, 2015:69). Marx yabancılaşmanın nedenini toplum düzeni olarak ileri sürerken; "Freudian yaklaşıma göre, yabancılaşmanın nedeni bireysel ruh hastalıklarıdır.” (Akyıldız, 1998:168).

"Nevrotik yabancılaşmış hasta yabancılaşmış bir insandır. Kendisini güçlü hissetmez. Korkmaktadır ve çekingendir çünkü, kendini eylemlerinin ve yaşantılarının öznesi ve yapıcısı olarak görmez. Yabancılaşmış olduğu için nevrotiktir." (Fromm, 2015:61). Fromm nevroz kavramını kullanarak yabancılaşmaya psikanalitik bir anlam kazandırır. O, Ben'in 
bir hastalığı olan yabancılaşmayı çağdaş insanın psikolojik sorunlarının başlangıcı, temeli olarak görür.

"Fromm yabancılaşma olgusuna psikanalitik bir boyut katarak, kavramı biraz daha belirgin hale getirmiştir. Fromm'a göre, geniş anlamda her nevroz yabancilaşma olgusunun bir sonucu olarak ele alınabilir. Çünkü nevroz bir tutkunun (örneğin: para, mevki, kadın vb şeylerin) tüm kişilikten ayrlarak başat duruma gelmesi anlamına gelmektedir." (Akyıldız, 1998:165). Fakat Fromm'un patolojik bir olgu olarak incelediği yabancılaşma, Marx'ta insan yaşamı üzerindeki somut koşulları ele alan evrimsel bir süreç ve kapitalist yaşam biçiminin bir zorunluluğu olarak mevcuttur. Kısaca, yabancılaşmış yaşam toplumsal süreçte bireyi bir robot haline getirir ve bu süreç bireyin kaçınılmaz psikolojik sorunlar yaşamasına neden olur. $\mathrm{Bu}$, bireysel ve toplumsal süreç olarak iki ayrı koldan yürür. Kierkegaard'ın kendisi olmak isteyen, istemeyen ve olamayan umutsuz kişileri bu iki sürecin elemanlarıdır. Ben'in kendi kendisini oluşturamaması, toplumsal beklentilerin ve değerlerin ben üzerindeki etkisi bir öteki ben oluşumunu tetikler ve bu da kendisine yabancılaşan bireydir; "Ĕger ben'imiz kendi kendini ortaya koysaydl yalnızca bir umutsuzluk biçimi var olurdu: kendi olmayı istememek, kendi ben'inden kurtulmayı istemek ve bu da şu anlama gelmektedir; kendi olmanın umutsuz istenci." (Kierkegaard, 2014:22).

Gerek patolojik gerek nevrotik psikozlar olarak ele alınan yabancılaşma, Marx ve Hegel'in bu olguyu insan evrim sürecinin zorunlu bir olayı olarak ele alması ile somut bir boyuta taşınmıştır. Fakat kabul edilen bu patolojik algıda bir sevgi yabancılaşması da söz konusu olmaktadır. Birey dış dünya ile ben'ini ayırt edebildiği zaman, dış dünyanın nesnel varlığını kabul edebildiğinde onu kavrayıp bir bütün olabilir; "Dünyayı henüz bir nesne olarak algılayamayan çocuk, usu ile kavrayıp birleşemez de. Insanın us etkinliğindeki bu ayrılı̆̆ yenmesi için yabancılaşması zorunludur" (Fromm, 2015:65-66).

Marx'ın bahsettiği sosyolojik süreç kapitalist gücün hız kesmeyen ilerleyişiyle gerçekleşmiştir. Sanayi devriminin ardından ilerleyen bilim ve teknoloji alanındaki gelişmeler ve insanın bu gelişmeler neticesinde makinaların egemenliği altına girmesi insanlar arasındaki iletişimsizliği ve bireyin kişiliğini yitirerek önce kendisi sonra da topluma yabancılaşmasını sağlar. Yabancılaşma olgusu 20. yüzyıl edebiyatında da sıklıkla kullanılan bir izlek haline gelmiştir. F. Kafka, A. Camus, M. Frisch gibi yazarlar eserlerinde çeşitli izleklerle yabancılaşma olgusunu işlemişlerdir. Yabancılaşan insanı ele alan bu eserlerde söz konusu izlekler dahilinde ana tema ise zaten yabancılaşmadır. 20 . yüzyıl edebi eserleri çok katmanlı bir yabancılaşma evreni yaratmıştır. İnsanın insanla, doğayla ve toplumla arasındaki zıtlık ve kopuşlar yabancılaşma olgusunu oluşturur. Bu eserler gerçeği yansıtmaktan ziyade onun ışığını kırar ve farklı açıdan yansıtır.

Yabancılaşma Türk edebiyatında ciddi anlamda 1970'lerden sonra görülmektedir. Bir izlek olarak karşımıza sıklıkla çıkan bu olgu kimi yazarlar tarafından metnin ana teması olarak kullanılmıştır. 1970'lerden önce Halit Ziya Uşaklıgil'in Mai ve Siyah'1, Ahmet Hamdi Tanpınar'ın Saatleri Ayarlama Enstitüsü, Yusuf Atılgan'ın Aylak Adam gibi eserleri de kesinlikle bireyin iç dünyasına eğilen eserler olarak önemlidir. Ancak yabancılaşma olgusunu bir sorunsal ve metnin ana izleği olarak ele alan ilk romanımız Yusuf Atılgan'ın 1959 yılında kaleme aldığı Aylak Adam romanıdır. Roman başkişisi C. sürekli bir içsel savaş halinde yaşayarak topluma karşı da bilinçli bir tavır almış durumdadır. 1972 yılında Oğuz Atay tarafından kaleme alınan Tutunamayanlar ise ilk postmodernist romanımız olarak yerini almıştır. Atay, aydın bireyin iç dünyasındaki iç hesaplaşmasını o güne değin Türk Edebiyatında başvurulmayan bir çok yeni tekniği kullanarak işlemiştir. 1983 yılında bu olguya kazandırdığı farklı izleklerle Sevgili Arsız Ölüm’ü kaleme alan Latife Tekin’e 
kadar bir çok yazarımız Türk edebiyatında yabancılaşma serüvenine katılarak önemli eserler vermişlerdir. Tekin, köyden kente göç eden insanların kentteki yabancılaşmasını fantastik öğeleri de içine alan büyü ile gerçekliğin harmanlandığı bir eseri kaleme almıştır. Bilge Karasu (Gece) ve Doğu - Batı sorunsalı toplumsal yabancılaşmayı ana izlek seçerek eserler veren Orhan Pamuk da Türk edebiyatında yabancılaşma olgusunu işleyen önemli yazarlardır.

Modernite, çağdaş yaşam ile birlikte insan hayatına etkili bir biçimde nüfuz eden, insanın içine düştüğü çaresizlik, iletişimsizlik ve aslında yalnızlık sanata da yabancılaşma olgusu ile önemli eserlerin ana izleği olarak yansımıştır. Batı edebiyatı için 20. yüzyıl başları olarak belirleyebileceğimiz bu algı Türk edebiyatı için seri bir biçimde 1970'lerden itibaren yayılmaya, işlenmeye başlamıştır. Postmodern algının, postmodern romanın da doğduğu bu dönemler için sanatın insanı yalnızlaştıran kapitalist sistemin üretim nesnelerinin görüntüsünü konu edindiğini görürüz. "Yirminci Yüzyllın başından itibaren sanatın gerçekliği temsil etme çabasının ortadan kalkmasıyla, nesnenin görüntüsünün yerine, nesnenin kendisi işlenen konu haline gelmiştir. Sadece kendisi olarak var olma çabasında, postmodern sanat içerikle ilgili neredeyse her şeyi malzeme olarak kullanır." (Aşkaroğlu, 2015a:11). Nesneyi öncülleyen, insana tümüyle yabancılaşmış bir dış dünya ile bu teknoloji toplumunda bir robotlaşan özüne yabancılaşan insanın gerçeği edebiyata yansitılmıştır. $\mathrm{Bu}$ durum geleneksel estetiğe alışkın okurun bu çağdaş metinlere uzaklaşması riskini taşımakla birlikte bir çağdaş toplum gerçeklidir; "Yeni kurmaca dünyada hiçbir şey kesin konturlarıla yer almaz; yeni sanatçı kendisine yabancı olan bir dünyayı yabancılaştırarak anlatır (...) yazarın amacı, okurunu yabancılaştırıp onun metne mesafe kazanmasını să̆lamak, böylece onu, kendisine sunulmuş bir gerçeği özümsemeye değil, metinden kendi gerçeğini üretmeye yönlendirmektir.” (Ecevit, 2005:258-259)

\section{Aylak Adam ve Yabancı Romanlarında Yabancılaşma}

Çalışmamızın bu kısmında 'Yabancı' ve 'Aylak Adam' romanı hakkında kısaca bahsedildikten sonra karşılaştırmaları bir biçimde iki eserin de ana izleği olan yabancılaşma olgusu incelenecektir.

Albert Camus'un kaleme aldığı ve 1942 yılında yayımlanan Yabancı sade ve kısa cümlelerle ilerlemektedir. Roman, uzun sayılmayacak bir zaman aralığında olup biter. Cezayir yakınlarında bir sahilde bir rastlantı sonucu ve planlamayarak işlediği bir cinayet sonrasında kendisini ölüme götüren süreci kayıtsızlıkla izleyen başkişi Meursault, yabancılaşmış bir bireydir. Romanda kahramanın adını öğrenememekteyiz. Yalnızca soyadı olan Meursault ismi verilmiştir. Zira annesinin ölümüyle anılması muhtemel bir ad olarak bu adın verilmesi gereklidir. Romanın yabancılaşma olgusu Marksist algıyla değil de daha çok Camus'un 'absürt' (saçma) felsefesiyle ilişkilidir. Meursault için hayat saçmadır. Bir arayış içerisinde değildir ve Nihilizm algısı romanın geneline yayılmıştır. Romanın diğer kahramanları olan Marie, Emmanuel, İhtiyar Salamano, Raymond, Celeste, Masson gibi isimler başkişi Meursault'un bakış açısında şekillenen derinlikte anlatılmışlardır. Yabancılaşmış, umursamaz bir bireyin algısına göre şekillenerek romanda var olurlar.

Aylak Adam, 1959 yılında Yusuf Atılgan tarafından kaleme alınmıştır. Eser, yazarın basılan ilk kitabı olması açısından da önemlidir. Önemli bir yarışmada ikincilik ödülüne layık görülen roman, döneminde yazarının yoğun bir ilgiyle karşılaşmasını sağlamıştır. Yayımlandığı yılların terminolojisinde modernist bir roman algısının, yabancılaşma olgusunun yer almayışı neticesinde anlamlandırılması zor olmuştur. Toplumcu gerçekçi romanların, köy romanlarının bir hayli baskın olduğu dönemde yepyeni bir renk olarak edebiyatımıza katılan Aylak Adam için edebiyat dünyasının bakış açısı ve uyum sağlaması 
oldukça önemli bir süreçtir; " Hemen hemen bütün anlatılarında diğer kahramanlardan farklı bir kişi merkeze oturur. Bu uyumsuz, yadırgatıcl, yalnız ve çaresiz baş kişi sayesinde yazar, fert üzerindeki toplum baskisin ele almaktadır." (Korkmaz, 2009:365). Onun metinleri için yapılan bu tespit adeta bir kü̧̈ük C. Portresidir. Eser dört ayrı bölüm olarak yazılmıştır. Kış, İlkyaz, Yaz ve Güz olarak kaleme alınan bu bölümlerle Başkişi C.'nin bir yıllık hayatı aktarılmıştır. Romanın başkişisinin bir adı yoktur. Romanda yalnızca C. ile karşımıza çıkmaktadır. Bu kahramanın toplumdan kopukluğuna, topluma dahil, ait bir birey olmadığına dikkat çekmek açısından önemli bir tercihtir. Onun toplumu reddetmesi, toplumsal düzene karşı çoğunlukla iç diyaloglar şeklinde karşımıza çıkan savaşı en büyük özelliklerindendir. Kahramanımız sürekli bir arayış içerisindedir ve bir varoluş çabasındadır. C. Sürekli bir aşk arayışı içerisindedir. O, doğru kadının peşindedir. Her zaman her yerde karşılaşmayı ümit ettiği o kadındır. Romanda bir çok anlatım tekniğinin kullanıldığı görülmektedir. Bilinç akıı̧ı, iç monolog, diyalog, geriye dönüş, günlük, mektup ve leitmotif tekniğine rastlanır. Roman, bir çeşit günlük yaşam eleştirisi olarak kaleme alınmıştır denilebilir.

Söz konusu iki roman arasında romanın temel yapısal unsurlarının işlenişleri bakımından da farklar bulunmaktadır. Aşkaroğlu'nun "Postmodern özellikteki romanlardan başka bir sapma ise, anlatılan mekân, kişi ve zamansal öğelerin ayrıntılarına girilmesi ve zamana, kişiye ve mekâna göre görecelik algısının asgari düzeye indirilmesidir.”(Aşkaroğlu, 2015b:253) ş̧eklinde eserinde karşılaştırmalı bir şekilde incelediği bu durum Aylak adam ve Yabancı romanında da karşımıza çıkmaktadır. Aylak Adam gerek farklı bakış açılarının devreye girmesi ile kişilerin psikolojik durumları ve karakterlerine derinlik kazandırması, gerek dört mevsim üzerinden bir aylağın arayışını, kendisi ve toplumla olan bir yıllık savaşını belirli ve etkili bir zaman diliminde vermesiyle önem taşımaktadır. Bu durum Aylak Adam'ın önemli bir modernist roman temsilcisi oluşunu en iyi şekilde örneklendirmektedir; "Modernist romanlarda, genellikle sağlam bir anlatı yapısı bulunur. Yazar, anlatısının başını, ortasinı ve sonunu belirli bir plan dahilinde, kişilerin davranışlarının arkasında yatan nedenleri de kapsayacak şekilde, uygun zaman ve mekân öğelerini de dahil ederek önceden planlar." (Așkaroğlu, 2015b:232). Aylak Adam'ın C.'sinin yabancılaşması Yabancı'nın Meursault'undan bu bakımdan da farklılıklar gösterir. Yabancı'da bu durum mekânsal tasvirler ve Meursault'un mekânsal değişimlerdeki ruhsal değişimleri romanın geneline yayılan derinliksiz algıya göre bir hayli derinleşirken kişiler ve zaman üzerinde duruş söz konusu değildir. Zaman, Meursault'un umarsızlğg ve kabullenişi eşliğinde onu ölüme götüren süreç olarak bir hayli sakin bir biçimde akmaktadır ve geçen zaman dilimi okuyucuya birden ve önem arz etmeyen bir oluşla aksettirilir. Kişiler ise yine Meursault'un sevmek kavramının vücut bulmadığı bir algı ile ruhunda şekillenen akisleriyle mevcutlardır. Derinliksiz ilişkiler ve amaçsız bir hayatın geçen sıradan günlerinin figüranlarıdır.

\subsection{Bireysel Yalnızlık : Beklentiler Ve Arayışlar}

Her iki kahramanı da tanımlayarak incelemememize başlarsak; bir tarafta babasından kalan emlak kiralarıyla geçimini sağlayan ve bu işi yaptırmak için dahi bir avukat tutarak, yalnızca yaşama eylemini gerçekleştiren, düşünmek, insanları gözlemlemek, yürümek, sinemaya, tiyatroya gitmek, sanatla, müzikle, edebiyatla ilgilenmek gibi zevkleri kendisine iş edinen bir aylak, C., diğer tarafta ise bir memuriyet işinde çalışarak geçimini sağlayan, kendi kazandığı para ile orta halli bir hayat süren ve kişisel zevkleri, insanlar üzerinde fikir ve etken eylemleri bulunmayan Meursault bulunmaktadır. Meursault sanki içinde yaşadığ 1 hayata uygun yaratılmamış gibidir. Çevresine adeta uyamamaktadır. O, çevresindeki her 
şeye yabancıdır. Bu durum $\mathrm{C}$. için de geçerlidir. Fakat aralarındaki fark; Meursault bu durumu sorgulamaz. Onun için toplumsal değerlerin, beklentilerin düşünülesi bir yanı yoktur. Meursault için bir öteki ben çoktan gelişmiştir ve bu hayatı o yaşamaktadır. Kabullenmişlik vardır.

Camus'un 'absürt' (saçma) felsefesi Yabancl romanının başkişisi Meursault'u doğurmuştur. $\mathrm{O}$, hayatı ve toplumu sorgulamayan, beklentilerden, hedeflerden arınmış bir birey olarak yaşamaktadır. Elindekileri reddetmez, fazlasını beklemez ve hırslardan bihaberdir. Bir şekilde karşısına çıkan insanların çabaları neticesinde kurulan ve derin anlamlar yüklemediği ilişkileri mevcuttur; "Yukarıya çıktık. Yanından ayrılacağım sırada bana, "Evde sicak şarap var," dedi, "isterseniz buyurun da bir-iki lokma bir şey yiyelim...” Bu sayade yemek pişirmekten kurtulacağımı düşünerek kabul ettim." (Camus, 2013:32). Yaptığı küçük hesaplar dahi bir arayış ve beklenti sonucu kendi çabasıyla oluşmamış şartlar neticesinde doğmaktadır.

Camus'un kahramanı kendi içerisinde firtınalar koparmayan bir yabancıdır. Toplumu eleştirdiği ve karşı çıktığı için değil, toplumsal normlara uyum sağlayabilecek bir karakteri ve hissiyatı olmadığ 1 için uzaktır. O, kendiliğinden ötekidir; "Raymond, insan kendini koyuvermemeli canım dedi. Önce anlamadım. Annemin öldüğünü ögrendiğini söyledi, ama bu zaten er ya da geç olacaktı dedi. Ben de öyle düşünüyordum." (Camus, 2013:36). Kendisine yöneltilen bir teselli cümlesindeki amacı anlayamayacak, içerisindeki mantıklı noktayı çıkarıp alabilecek kadar değerlere uzaktır.

C. ise kolektif, toplumsal nitelikli bir kuralsızdır. Onun bireysel anomisi içinde yaşadığı toplumla bağlarının gevşeyerek kopması sonucunda yaşananların ruhsal yansımalarını, bireysel kuralların, değerlerin kopuşunu karşılamaktadır. C., hiçbir ölçüsü, süreklilik durumu olmayan ve toplumsal normları yadsıyan ve yükümlülük duymayan bireyin kendi ruhsal bozgunu olarak bahsedebileceğimiz bir bireysel anomi kişisi olarak karşımıza çıkmaktadır. C., topluma karşı uzaklaşma ve bireysel yabancılaşmasını Meursault gibi isyansız, arayışsız bir birey olarak gerçekleştirmez. C.'nin yabancılaşması topluma, onun birey üzerindeki beklentilerine ve yaşamın kendisine olan eleştirileri, zıtlıkları üzerinden somut bir süreçte gerçekleşmektedir. O, Türk romanının flaneurudur.; " $O$ bir flaneurdur. Flaneur, modern hayata salvverilmiş öneml, bir simgebirimdir. O boş gezen, savurgan bir kişidir." (Ünaldı, 2011:144).

C.'nin toplumsal beklentilere ve kabul görmüşlüğe karşı geliştirdiği ve onun yabancılaşmasının bir anomi karakteri oluşunun yanı sıra onun içsel savaşında ve benliğini oluşturan değerler arasında yegane savaşı babası ile gerçekleşir. O, babası gibi olmamak adına yaşamakta ve kararlar almaktadır. Onun en büyük çıkmazı aslında baba figürüdür; "Ama o yapmıyordu; soymayacaktı kadını. Să̆ bacă̆ını büküp dizini kaşıdı. Babasına benzemekten korkuyordu. Çocukluğunda, eski evde sık sık somya gıcırtıları duyardı. Bir gün mutfakta babasın görmüştü: kopacak gibi gergin, sırtı kamburlaşmış, arkadan kadının kalçalarına sarılmış. Elindeki bardak düşünce doğruluvermişlerdi. Korkunçtular. Babası yürümüş onu tokatlamıştı. On yaşındaydı. Kadınlığı, erkekliği biliyordu. Eskiden beri, belki teyzesi yüzünden, hep iğrenirdi babasından." (Atılgan, 2015:12). Çocukluğundan beri zihninde şekillenen baba figürü ile savaşır ve onun annesi olarak zihninde ve hayatında şekillendirdiği varlığa yani teyzesine karşı olan ilgisi ve tacizleri yüzünden nefretini her daim artıran bir adamdır babası. C, öyle bir otorite ve sevgi boşluğunda büyümüştür; babasızlık.

Küçük yaşta annesini kaybeden $C$. için anne figürü teyzesi ile vücut bulmuştur. Bir çocuğun anneye yükleyeceği tüm anlamlar $\mathrm{C}$ tarafindan teyzesine aktarılmıştır; "Beni 
Zehra teyzem büyüttü. Onu kıskanç, bencil bir sevgiyle severdim." (At1lgan, 2015:121). Teyzesi Zehra onu büyütmüş ve her daim sıcak, şefkat dolu dokunuşlarla onu sevmiştir. Fakat bu kız çocuklarıyla erkek çocukları arasında çeşitli farklarla tezahür eden durumlar yaratabilecek bir olgudur. Anne arketipi erkek çocuklarında farklı biçimlerde gelişebilmektedir. C. için de bu durum onun her daim anne-sevgili bulma çabasındaki bir arayış olarak tezahür etmiştir; "Müstakbel erkeğin karşılaştı̆̆ ilk dişi yaratık annedir ve anne, açıkça ya da gizlice, kabaca ya da nazikçe, bilinçli ya da bilinçsiz, oğulun erkekliğini ima etmeden duramaz; oğul da annenin dişiliğinin giderek farkına varır ya da en azından bilinçsizce, içgüdüsel olarak buna yanıt verir.”(Jung, 2003:25).

"Babam bir koluyla teyzemin etekliğini kaldırıp sarmış, öteki eliyle çıplak bacaklarını okşuyordu. 'Zehra, şu bacakların yok mu?' dedi. Çevrem kararır gibi oldu. Fırladım. Üstlerine atıldı̆̆ımda bacaklar hala çıplaktılar. '-Bırak onu diye bağırdım...' Elini ısırdım;... Kafamdaki ses durmadan, 'Kulă̆ı yırtıldı,' diyordu.” (Atılgan, 2015:122). Roman boyunca C, baba arketipinin izlerini davranışlarında yaşamıştır. Kadınlara karşı duyduğu ilgiden dolayı kendini suçlayan ve kadınların bacaklarına dokunamayan bir psikoloji geliştirmiştir. Romanda leitmotiv olarak "Kulağını kaşıdı" cümlesi yukarıda yaptığımız alıntıdan anlaşıldığı gibi kötü bir çocukluk anısının tik olarak kalan izidir. Burada C'nin babası ile Zehra teyzesi arasında yaşanan cinsel ilişkiye gösterdiği tepki Ödipal kompleksi ile açıklanabilmektedir; "kadın için anne, cinsiyetin belirlediği bilinçli yaşamın misalidir. Oysa erkek için anne, örtük bilinçdışının imgeleriyle dolu, henüz tanımadı̆̆ bir yabancıdır. Salt bu nedenle bile, erkeğin anne kompleksi kadınınkinden tümüyle farklıdır. Erkek için anne en başından beri son derece simgesel bir karaktere sahiptir, erkeğin anneyi idealize etme eğilimi de bundan kaynaklanlyor olsa gerek." (Jung, 2003:41). Karmaşık bir ilişkinin beklentilere yansıması da bu tezi doğrular gibidir; "Arada eğilir, ben büyük, inanılmaz bir şeyler olacă̆ını beklerken salt burnumun ucunu öperdi." (Atılgan, 2015:10). Zehra, masallar anlatarak, oyunlar oynatarak C'nin hayatı boyunca mutlu olduğu yegane zaman diliminin kahramanı olmuştur. Fakat bunun bir erkek çocuğunun yaşaması muhtemel ödipal kompleksi olarak ele alınıp işlenmesi dışında travmatik unsurlar kazanarak C'nin bireysel yabancılaşmasındaki en önemli unsur haline gelmesi yukarıda da bahsettiğimiz gibi “babası gibi olmamak” çabası ile gerçekleşmiştir. Ahmet Kabaklı ise Atılgan'ın Anayurt Oteli ve Aylak Adam romanlarındaki ilgili kısımları inceledikten sonra yazarın felsefi ve psikolojik anlamda çeşitli kuramlar ve teoriler üzerinde yoğunlaşan yazar ve düşünürlerin denek alanı olarak söz konusu romanları kullandığını öne sürer: “... Burada ve romanın bütününde, Freud'a iman ölçüsünde inanmış bir adamın ruh tahlilleri görülüyor. Her iki romanda C'nin de Zebercet'in de hemen bütün benlikleri ve çevreleri kadınla cinsellikle, çok yerde lüzumundan fazla açı sözler ve sahnelerle doludur. Bazan öyle gelir ki, Atılgan, iki kahramanını ve öbür figürleri, Freud'un (sonunda bir kısmı Adler ve Yung tarafindan çürütülmüş olan) nazariyeleri için bir uygulama alanı yapmıştır. Her satırında Freud'un insan ruhunu erotik açıdan kurcalayan bir kehaneti dile gelmektedir.'(Kabakl1, 1997:865).

Onun kutsalına zarar veren baba figürü C'nin bir erkek olarak kararlarında ve kadınlara yaklaşımındaki yabancılaşmasına en büyük etken olmuştur; "Babamda korkunç bir kadın düşü̈nlügü vardl. Onun gibi olmama kararını bu iğrençlikleri gördükçe vermiş olacă̆ım.” (Atılgan, 2015:121). O, babası tarafından sunulan her şeye karşı çıkmıştır. ailesi tarafından verilen adı reddetmekle, kadınlara karşı duyduğu cinsel ilgiden dolayı kendini suçlamakla, hesapsızca para harcamakla ve bir işte çalışmamakla babasına benzememeye ve aslında ondan kendisine göstermediği babalık şefkatinin öcünü almaya çalışır. Romanın adı da bu öç alma duygusunun büyüklüğünü göstermektedir. 
Camus'un Meursault'unu yabancılaştıran en büyük özelliği kabullenmişliğidir.Annesinin ölmesine üzülmemesinin asıl nedeni de bu kabullenmişliktir. Romanın ilk cümlesi olan "Bugün annem öldü. Belki de dün, bilmiyorum." (Camus, 2013:11) ile Meursault'un kendisine, değerlere, topluma ne denli yabancılaştığını görebiliriz. O, ölümü, yaşamı, hayatın bize verebileceği iyi ve kötü her şeyi kabullenmiş bir bireydir. C'nin kişiliğinde oldukça net gördüğümüz toplumsal yabancılaşma ve toplumun dayattığ 1 değerlerin değersizleşmesi Meursault'un tüm benliğini kaplamıştır. Hem bireysel, hem de toplumsal yabancılaşma süreci Meursault için evrimini tamamlamış bir boyuttadır; “Öteki, Ben'in sintrlarını belirleyen, olanaklarını keşfettiren ve zaman zaman Ben'i tanımlayan, tamamlayan niteliğiyle olumlu bir değer olarak kabul edilir. Ancak bu değer, Ben'in otantik varlı̆̆ını sınırladı̆̆ ve onu 'benzeri kılarak' yok etmeye çalıştı̆̆ andan itibaren de bir tehdit algısına dönüşür.” (Korkmaz, 2008:17).

Meursault için değerler yitimi gerçekleşmiş, ötekileşen benliği her manada yabancılaşmıştır. Babasını hiç tanımadan geçirdiği çocukluğu ve yetişkinliği bir otorite ve baba sevgisinin boşluğunda geçmiştir. Onun için iyi yahut kötü manada bir baba figürü yoktur. Roman boyunca sevdiğini söylediği yegane varlığın annesi olduğunu görmekteyiz. Annesini sever fakat kabullenmişliği onun üzüntü, sevinç gibi duygularını da köreltmiştir. Annesinin ölmesi onun Meursault'un dünyasında yalnızca nihayetinde bir gün olacak olan şeyin gerçekleşmiş olmasından ibarettir. Annesinin ölüm haberini aldığında tüm umursamazlığı karşısında aklında kalan tek şey patronunun verdiği tepkidir: "Patrondan iki gün izin istedim, böyle bir mazeret karşısında isin vermemezlik edemezdi. Ama pek de memnun görünmüyordu. Hatta ona, "kabahat bende değil," dedim. Cevap vermedi. $O$ zaman 'keşke böyle demeseydim' diye düşündüm." (Camus, 2013:11). Bu ifadede ilk kez karşımıza çıkan "kabahat bende değil" sözleri birkaç yerde daha görülmektedir. Buradan annesinin ölümüyle alakalı, onun evinde değil de bir bakımevinde ölmesinden dolayı hissetmesi muhtemel bir suçluluk duygusu sezilebilmektedir. Fakat Aylak Adam C.'nin yaşamındaki tek güzel ve kutsal insan olarak varolan anne figürü burada karşımıza çıkmamaktadır. Meursault sarıp sarmalayıcı, kuşatıcı ve sevginin en kutsal haliyle var olan anne arketipine sahip değildir. Anne, Meursault için sevmemek için bir sebebi olmadığ1, kendisi tarafından sevildiğine emin olduğu bir insandır. Fakat bu, yabancılaşmasının, onun ötekileşmesinin boyutlarının buraya kadar taşmasını engellememektedir. Annesinin cenazesine gittiği gün; "Güzel bir gün olacaktı. Çoktan beri kırlara gitmemiştim, annem olmasa gezip dolaşmaktan ne kadar hoşlanacağımı hissediyordum.” (Camus, 2013:19) düşüncesiyle mezarlığa ilerleyen bir karakterdir.

Meursault'un yabancılaşma süreci, romanda anlatılan olaylar başlamadan çok daha önce sonlanmış bir durumdadır. O, ötekileşme evrimi tamamlamış ve bu süreçte eleştirmek, karşıt bir görüş ve karakter geliştirmek gibi bir eylemi olmadığı topluma, nihayetinde en çok da kendisine, benliğini ören değerlere yabancılaşmıştır; "Ötekileşmenin, en trajik boyutu, kişinin, kendini vareden değerleri yıkan gücün kendisine dönüşmesidir.” (Korkmaz, 2008:19). Meursault, Kierkegaard'ın 'bir ben'i olduğunun farkında olmayan umutsuz kişisidir.

Meursault, aşk - sevgi gibi kavramlara da yabancılaşmış bir bireydir. O, bir arayış içerisinde değildir. Sevmek, aşık olmak onun için saçma duygulardır. Hayata dair böyle bir beklentisi yoktur. Zira aldığı evlenme teklifini de düşündükten sonra mantıklı bularak kabul eder; "Akşam, Marie beni görmeye geldi, kendisiyle evlenmek isteyip istemediğimi sordu. Benim için farketmediğini, ĕger o istiyorsa evlenebileceğimizi söyledim. (...) O da evliliğin ciddi bir iş olduğunu belirtti. Ben, "Yoo" diye cevap verdim." (Camus, 2013:43). Meursault 
nasıl olsa bir gün öleceğini kabullenmiştir ve öldüğünde evli olup olmamasında bir fark görmediği için bu cevabı vermiştir. Onun için sonunda varılacak nokta aynıdır ve hayatın bir amac1 yahut anlamı yoktur.

Meursault için aşk, sevgi yerine arzulamak, cinsel istek duymak önemli duygulardır çünkü hissettiği şey de tam olarak budur. Riyakârlık etmez, yalan söylemez; "Biraz sonra, onu seviyor muyum diye sordu. Ona bu sorunun manasız olduğunu söyledim, galiba hayır diye de ekledim. Mahzunlaştı. Ama öğle yemeğini hazırlarken hiç yoktan öylesine güldü ki onu öptüm." (Camus, 2013:38). Sevmek kavramının ne anlama geldiğini bilmemektedir. Marie'i arzular, onunla vakit geçirmek hoşuna gider fakat bunun sevgi olup olamayacağını sorgulayamayacak kadar uzak ve yabancıdır; "Karşılıklı cinsel doyum, ikili uyum ve yalnızlıktan kaçma olarak sevgi, çağdaş batı dünyasında yozlaşan sevginin iki normal biçimidir. Bunların her ikisi de toplum tarafindan biçimlendirilen sağllksız sevgililerdir." (Fromm, 1987:93). Sahip oldukları tüm değerlerine yabancılaştı̆̆ı toplumun yabancı bir bireyi olan Meursault, yozlaşan ilişkisiyle onlara benzemektedir.

C’nin sadece canı sıkıldığı için dört ay süren bir fakülte hayatını sonlandırır. Buna rağmen uzun bir eğitim neticesinde kazanılması muhtemel beğeniler ve ilgi alanlarına sahiptir. Bu Flaneur aynı zamanda bohem bir hayata sahiptir . Sanatla içli dışlıdır. Özellikle sanatın resim ve edebiyat gibi kimi dallarında bilinçli bir okuyucu ve izleyicidir. Arkadaş çevresi de bu çevrelerdendir. Ressam arkadaşları vardır. Hatta, biricik idealinin peşinden gidişi dışında yaptığ 1 tek iş olarak, ara sıra onlara atölyelerinde öğrencilere modellik yapar. Meursault'ta olmayan bir güzellik ve zevk arayışı vardır. O, umutsuz değildir. Umut eder ve toplumsal normların belirlediği değil, kendi benliğinde iyi ve güzel olarak yansıyan nesne, değer ve insanları arar. Aşk da bunlardan biridir.

C'nin aylaklığı bir başkaldırıdır. Toplumun derinliksiz ilişkilerine, nesneye, tüketime verilen öneme, tensel teması öncülleyen cinsel ilişkiden ibaret algıya karşı bir karşı duruştur. Onun aylaklığı toplumdan bir geri çekilme çabasından değil, yeniden doğuş için bir eleştiridir. $\mathrm{O}$, kalabalığın içindeki yabancı, ötekidir. Aşk, $\mathrm{C}$ için önemlidir. O, aşkın, sevginin varlığına inanmaktadır. Meursault gibi aşk bağlamında topyekün kaybedilen bir yabancı değildir. Sokaklarda her daim hayalindeki aşkı aramaktadır. Ayşe ile olan ilişsileri araya giren zaman dilimleriyle romanın bütününe yayılmıştır fakat zihnindeki gerçek aşkın o olup olmadığı konusundaki gelgitler nihayetinde son bulur; "Anamın, babamın varlığına dayanamıyor. Neden her şeyi bendenbekliyor? Kendi ölü babasının bile varliğına dayanamazken!.." (Atılgan, 2015:133) sözleriyle Ayşe'nin de “O” olmadı̆̆1 konusu neticelenir. Roman, aylak adamın hayatını sembolize eden dört mevsim boyunca onun gerçek sevgiyi bulma çabasını anlatır. Fakat o gerçek sevgiyi dört mevsim boyunca bulamayacaktır. Kitapta karşımıza B olarak çıkan ve defalarca aynı yerlerden geçtiği kadındır aradığı gerçek sevgi. Roman, B'nin arkasından koşarak bindiği otobüse yetişemediğinde ağzından çıkan şu sözlerle son bulur; “ Yıllardır aradığını bulur bulmaz yitirmesine sebep olan bu saçma, alaycı düzene boyun eğmiş gibi kendini koyverdi. Şimdi ona istediklerini yapabilirlerdi. ... " (Atılgan, 2015:154). Bu, onun gerçek sevgiyi arayışının sonudur. 


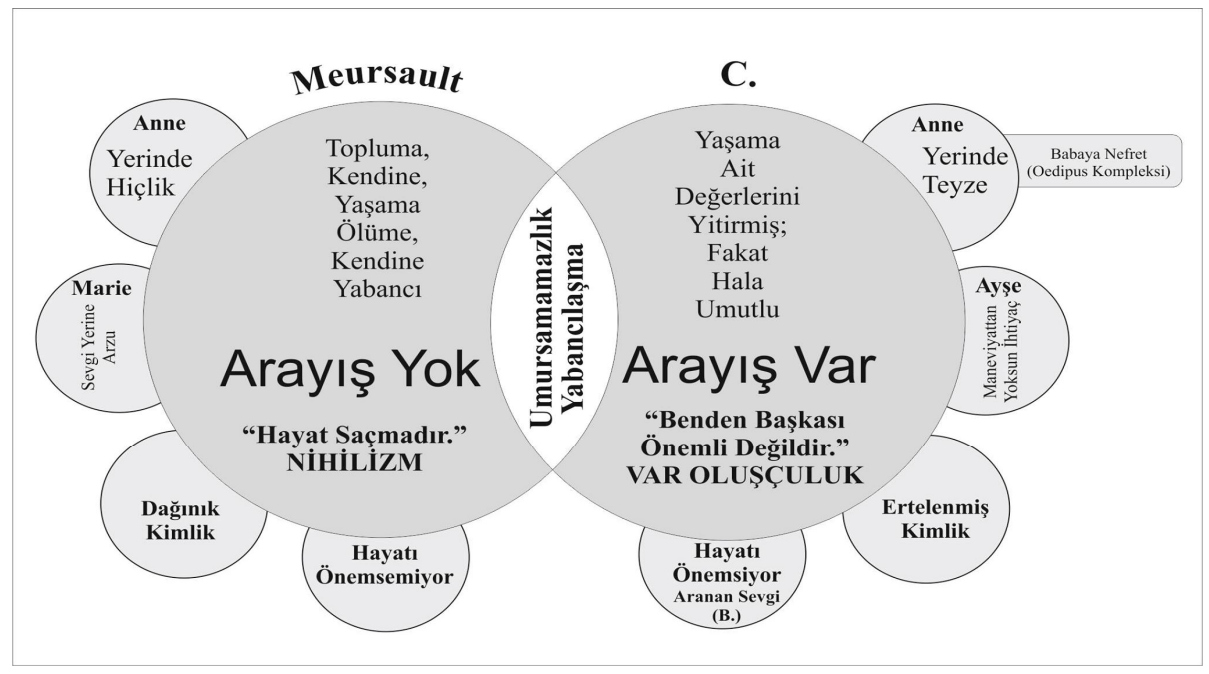

\subsection{Toplumsal Yabancılaşma}

Bireyin toplumsal bir süreç içerisinde yaşadığı psikolojik bir durum olan yabancılaşma, bireysel etkilerini toplumsal bir süzgeçten geçirdiği değerler karmaşasının neticesinde gösterir. Freud'un tanımında yer alan insanın kötü ve vahşi bir varlık oluşunun tedavisi toplumdur. Toplumun insanı ehlileştirmede en önemli etken olduğu görüşüne sahiptir. Bu uygarlık seviyesi toplumsal süzgeçlerden geçerek sağlanmaktadır. Nitekim yabancılaşma bu durumla doğru orantılı olarak ilerler modernitenin getirdiği uygarlık seviyesi arttıkça birey toplum içerisinde yalnızlaşır ve yabancılaşır.

"Yabancılaşmış biri kendisine özgü duygu ve düşüncelerini dışındaki bir nesneye aktarmış olduğu için artık kendisi değildir. Onda hiçbir 'ben' ya da kimlik duygusu yoktur." (Fromm, 2015:65). Yabancı, bunun en iyi hissedildiği roman olarak karşımıza çıkmaktadır. Meursault ben ve kimlik duygusunu kaybetmiş bir birey olarak yaşamaktadır. Kendi yaşamı da dahil olmak üzere tüm yaşamlara ve gailelere o kadar kayıtsızdır ki ölümün nihai son olduğu bir yaşamın anlamsızlığı Meursault kimliğinde sürekli vurgulanır. Meursault kavurucu güneşin onda yarattığı bunaltı yüzünden sebepsiz yere silahı çıkarır ve güneşin kavurucu sıcaklığının öcünü alıyormuşçasına sahildeki Arap'ı öldürür. Bu cinayeti sanki kendi iradesi dışında işler ve tutuklanır. Mahkemede, sanki yargılanan, hayatı söz konusu olan kendisi değil de, bir başkasıymış gibi, olan bitenleri, anlamayan, kayıtsız bir gözle seyreder; yaptığına bir açıklama şekli bulmaya uğraşanlara, bir anlam vermek için çaba harcayanlara şaşırır ve kendisini müdafaa etmek için dahi çaba sarf etmez. Fromm' un; "İnsanın nasıl yaşaması gerektiğini öneren varoluş ilkeleri bu ilkelerin çiğnenmesini, günah ve suç kavramını sezdirir." (Fromm, 2015:85) cümlesindeki günah ve suç kavramları Meursault için toplumun kabul gördüğü biçimde algılanmış bir gerçeklik değildir. Zira $\mathrm{O}$, toplumdan değildir. Meursault romanda baştan sona hissedileceği şekilde çevresine, orada yaşanan hayata uygun bir biçimde yaratılmamış gibidir.o, çevresindeki her şeye yabancıdır.

"Ben tramvaydaki bir sıranın önündeydim, bütün bu kim oldukları belirsiz yolcularsa gülünç taraflarını bulmak için yeni geleni gözleriyle didik didik etmekteydiler. Aptalca bir fikirdi bu biliyorum, zira onların burada peşinde oldukları bir insanın gülünç tarafı değil, 
cinayetti. Bununla beraber aradaki fark pek o kadar büyük değil ve aklıma da böyle bir düşünce geldi ne yapayım.” (Camus, 2013:78)

Meursault çabalamaz, cinayet işlediği ve tutuklandığı sırada, ölümle yüz yüze geleceği gerçeği karşısında dururken dahi olayları gülünç ve saçma bulur. Kayıtsızdır. C için durum pek böyle sayılmaz. O, yabancılaştığı toplumun yargıcıdır. Her an her yerde içi boşalmış toplumun eleştirisini yapar. Kendisini soyutladığı toplumun karşısında dikilmek için sebepler arar, gözlemler ve tüm bunları önemser. Kayıtsız değildir. "Ben başkayım" (Atılgan, 2015:15) der. Kendisini üstün gördüğü ve içinden soyutladığı toplum tarif edebilecek kadar bilinçlidir. Romanın ilerleyen sayfalarında karşılaştığımız sevgilisi Güler ile de onun 'eli paketliler'den biri olduğunu düşünmesinden dolayı ayrılır. C'nin eleştiri ve yargılamaları toplum için oldukça sert bir biçimde gerçekleşir. Kabullenmişlik halini aylak adamda göremeyiz. O, varoluş sorgulamasında ısrarlı ve iyi olanı arama konusunda istekli bir yabancıdır. Ahmet Alver'e göre; “Yusuf Atılgan'in Anayurt Oteli'nin(Atılgan 1972) Zebercet'inin ve Aylak Adam'ın (Atılgan 1959) ana kahramanı C. 'nin şahsında modern yaşam koşulları karşısında yabancılaşan, yalnızlaşan, sevgisizleşen ve ardından da hayattaki beklentilerinde uzaklaşarak şizofreniye tutulan sevmeye ve sevilmeye hasret aydınlarl görmekteyiz."'(2012:30)

$\mathrm{O}$ bir Flaneurdur. O boş gezer, bir işi yoktur; " kalabalıklar onun mekânıdır. Kalabalıklarda yaşamayl sever ama onlardan biri olmaz. Pasaj, sokak, cadde gibi kentsel mekâna dahil olan yerler 'aylak' in evidir. O, serbest zamanı içinde kalabalık kent mekânlarında moderni gözlemlemekle adeta bir dedektif gibi davranır." (Ünald1, 2011:144). Kalabalıklar içinde kaybolmaz. Onlardan değildir. O, toplumda keşfettiği aksaklıklar için kafasında kurduğu ütopyadan sahneler belirler. İçi boşalmış olarak gördüğü bu toplum için kimi zaman ütopik, fantastik çözümler üretir. Sonra yine sokakla, içinde aylak dolaştığı toplumla çelişir. Yenilmez, savaşır.

Meursault'a Ait Yaşam Düzlemi

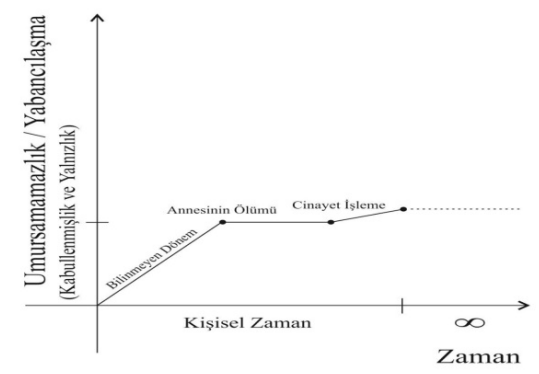

C.ye Ait Yaşam Düzlemi

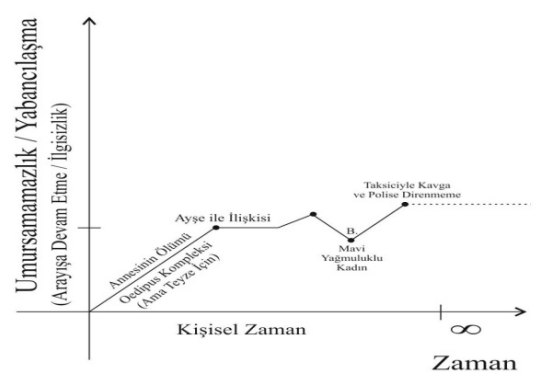

Aylak adam, kimi zaman bir ressam, bazen bir gazeteci, bazen bir yazar, kimi zaman bir sosyal bilimci, ve işte gözlemlemenin verdiği zevki sürdürmesini sağlayan bu amatör dedektif sık sık modern dünyayı izler. İnsanların gündeliğini, sıradanlığını inceler.

Evlilik Aylak adam için topluma başkaldırının en önemli kaynaklarından biridir. Meursault'un kabullenmişliği, Marie'nin teklifi karşısındaki umursamaz tavrı ve "benim için farketmez" hali C için söz konusu değildir. Meursault evlilik kurumunu da sorgulamaz. Onun için yalnızca toplumdan soyut yabancı bir birey olarak arzu edilmesi gereken bir durum değildir fakat üzerinde düşünülecek ve karşısında durulacak bir önem de teşkil 
etmez. Etmesi için bir sebep yoktur. Aylak adam ise bulunduğu topluma yabancılaşmış birey olarak bu kuruma karşıdır. O, evlilik dıșı birliktelik arayıșındadır; " Çevrene bakmıyor musun? En mutlu görünenlerine bile? Bütün bunlar üç oda, bir mutfak, iki çocuk düşü ile başlıyor. Sonra? Haydi bayanlar baylar! Bu firsatı kaçırmayın. Siz de girin siz de görün." (Atılgan, 2015:76). Onun yabancılaşması sorgulamalarının önünde bir engel değildir, ancak neredeyse tüm ilişkilerine sinen bir kısırdöngü içindedir; " $C$. Başta yalnızdır; derken aradı̆̆ı kızı bulduğunu sanır ve umutlanır sonra hayal kırıklı̆̆ına uğrar. Ayşe ve Güler ile giriştiği ilişkilerde aynı evreleri gözlemleriz.” (Moran, 1994:219).

Meursault'un yabancılaşması toplum için öyle bir hal alır ki romanın sonunda idam cezasına çarptırılması roman boyunca ötekileşen toplum ve dünya algısının bir sonucu olarak meydana gelir. Suç, kabahat, üzülmek, yas tutmak, toplumun tavır ve beklentileri gibi meseleler üzerinde doğru düşünemeyen, bu algıya sahip olmayan gerçek bir yabancıdır O. Annesinin öldüğü günün ertesinde sahile gidip bir kadınla güzel bir gün geçirmesinin buradaki asıl mesele olduğunu ayırt edememektedir.

Meursault, yaradılış itibariyle bir ötekidir. Annesinin cenazesi başında ona kahve ikram eden adamın ifadeleri, ağlamayışı, annesinin ölümünün ertesi gününde yaptıkları, savcının onu bu mevzularla köşeye sıkıştırması Meursault için anlaşılır şey değildir. Anlamaz. Kabullenir. Kabullenmişlik bu yabancıyı romanın sonunda ölüme götüren sebep olarak karşımıza çıkar. Korkmaz'ın; “Kişinin kendini çevreleyen şeyler dünyasında yitip gitmemesi için onun, tarihselliğini să̆layan bellek mekanlarına tutunması orada kurduğu kendilik bilinci ile hem uzamsal boyutta dünya ile hem de zamansal boyutta toplumsal geçmişiyle bağlantıya geçmesi kaçınılmaz bir gerekliliktir." (2008:31) şeklinde ötekileşme sorununu incelediği bu sözleri yabancılaşmanın sosyal boyutta önüne geçme durumuna değinir. Meursault'un ise onu çevreleyen 'hiçlik' evreninde bir sebebi, bir değeri yoktur.

C. rutinin ve alışılmışın dışına çıkmak, farklı olanın peşinde koşmak için bütün gün boyu onun için rutinleşmiş şeylerin içinde karamsarlaşmakta, aradığını kendi rutininin içinde bulamamaktadır. Meursault'un rahatsız olmadığı bozmak için bir sebep bulamadığı düzeninden bu düzene bakış açısından çok daha farklı bir anlayışı vardır C'nin. C ise bu sebepten huysuzlaşmakta, kendisini de diğer fertlerine yaptığı gibi gündelik işler ve yozlaşmış çarkın içinde öğütmeye çalışan bir birey haline getirmek isteyen topluma, insanlara, kurumlara tavır almakta, onları yaptığının tam tersini yaparak, onlara karşı gelerek hayatını sürdürmeye çalışarak bunu bir yaşam tarzı olarak benimsemektedir.

O, topluma aykırı düşen tavırları gerçekleştirmekten adeta zevk alır. Simit yiyerek yürüyor. Tek tük geçenler, dönüp ona bakıyorlar; "Kıllğı düzgün bir adamın sokakta simit yemesi yasaktır. Bütün yasaklar gibi bunun da bir kaçamak yolu yok mu? Simidi kır, cebine sok. Tek elinle bir lokma koparı, kimseye sezdirmeden ağzına at. Ama ben dişlerim sağlamken ısıracă̆ım." (Atılgan, 2015:13). Bu durum yalnızca simit yemek ile değil, günlük rutinin her alanında karşı koymak istediği her olay, her toplumsal algı için geçerlidir.

Berna Moran C.'i ; "Ne ki aylak adam C. Kendine güveni olan zeki, güçlü paralı bir adamdır." (Moran, 1994:219) ş̧eklinde tanımlar. C, aktif, düzene karşı ve eleştirel bir yabancıdır. Onu toplumdan eğreti eden, yabancılaştıran her türlü değerin farkındadır ve karşısında aktif bir duruş sergiler. Meursault ile C. yabancılığı ortak bir paydada eriten fakat farklı karakterleri ve yaklaşımlarıyla toplumsal yabancılaşmanın kahramanlarıdır. 


\section{Sonuç}

Yabancılaşma kişinin mevcut bilinç eşiğini yitirerek yaşama bakışının, değerleri algılayış biçiminin, bulunduğu mekânının, bireyin kendiliğinin kaybolması halidir. Bireyin anlamsızlık hali içerisinde toplumdan dışlanma duygularını hissetmesidir. Her şeyin anlamının yitirmesi ve saçmalaşmasıdır. Yabancılardan kiminin buna bir çözümü, ütopik bir evreni mevcutken kimisi tamamen kayıtsızdır.

$\mathrm{Bu}$ çalışmamızda yabancılaşmanın tarihsel serüveninden bahsederek, edebiyata uğradığı ilk yıllardan itibaren Türk edebiyatındaki yerini anlattık. Aylak Adam ve Yabancı romanındaki roman kahramanlarıyla yabancılaşma olgusu arasında ilişki kurarak kahramanların yabancılaşma süreçlerine ve boyutlarına değindik. Roman kahramanlarının yabancılaşma serüveninde etken olan modernitenin, teknoloji ve bilimle paralel ilerleyen toplumsal gelişmelerin ve değişen algının, Batılı yaşam biçiminin önemine değindik. Çalışmamızın ilk bölümünde çeşitli düşünür ve yazarların fikirleriyle temelleri atılan yabancilaşma olgusunun tarihsel serüveni ve bunun edebiyattaki kurmaca karakterler ve toplum üzerindeki yansımalarına değinilmiştir.

İkinci bölümü ise Yusuf Atılgan'ın C olarak adlandırdığı isimsiz kahramanının yabancılaşma serüveni Albert Camus'un Yabancısı Meursault'un yabancılaşması ile karşılaştırmalı bir biçimde incelenmiştir. Arayışsız, amaçsız bir hayat süren Meursault'un yabancılaşması korkunç bir kabullenmişlikle karşıladığı bir biçimde onu ölüme götürürken, roman boyunca sıyrıldığı yabancılaştığı toplumda bir arayış içerisinde bulunan $\mathrm{C}$ için roman arayışını sürdürürken son bulur. Bu arayışını sürdüren aylak adamın yabancılaştığı toplumda sürekli bir şeyleri eksik hissederek sürdüğü kaygılı ve arayış halindeki yaşamının devamını okuyucuya belli eder.

\section{Kaynakça}

ACEHAN, Abdullah, "Fahim Bey ve Biz, Anayurt Oteli ve Aylak Adam Romanlarına Psikolojik Bir Bakış", Motif Akademi Halk Bilimi Dergisi, 2012-1 (Ocak-Haziran) (Balkan Özel Sayı1-I), s.128-152.

AKYILDIZ, Hüseyin, "Bireysel ve Toplumsal Boyutlarıyla Yabancılaşma", Süleyman Demirel Üniversitesi, Iktisadi ve İdari Bilimler Fakültesi Dergisi, Y.1998, S.3 (Güz) s. 163176.

ALVER, Ahmet, "İlk Dönem Romanlarında Yanlış Batılılaşma Sonucu Yabancılaşan Karakterler", Dede Korkut Türk Dili ve Araştırmaları Dergisi 1.2., 2012.

AŞKAROĞLU, Vedi, Postmodernizm Sinırsız Özgürlük mü? Özgürlüğ̈̈n Sinırı mı?, Karadeniz Dergi Yay., Ankara, 2015a.

AŞKAROĞLU, Vedi, Postmodern Söylem/ Ihsan Oktay Anar \& John Fowless, Karadeniz Dergi Yay., Ankara, 2015 b.

ATLIGAN, Yusuf, Aylak Adam, YKY, İstanbul, 2015.

CAMUS, Albert, Yabancl, Can Yay., İstanbul, 2013.

ECEVIT, Yıldız, “Ben Buradayım...” Oğuz Atay’ın Biyografik ve Kurmaca Dünyası, İletişim Yay., İstanbul, 2005

FROMM, Erich, Sevme Sanatı, Payel Yay., İstanbul, 1987.

FROMM, Erich, Psikanaliz ve Din/ Freud, Jung ve Din Algisl, Say Yay., İstanbul, 2015. 
FROMM, Erich, Yeni Bir İnsan Yeni Bir Toplum/ Yanılsama Zincirlerinin Ötesinde, Say Yay., İstanbul, 2005.

JUNG, Carl Gustav, Dört Arketip, Metis Yay., İstanbul, 2003.

KABAKLI, Ahmet, Türk Edebiyatı 5., Türk Edebiyatı Vakfı Yay., İstanbul, 1997.

KIERKEGAARD, Soren, Umutsuzluk Ölümcül Hastalık, Doğu Batı Yay., Ankara, 2014.

KORKMAZ, Ramazan, Aytmatov Anlatılarında Ötekileşme Sorunu ve Dönüş İzlekleri, Grafiker Yay., Ankara, 2008.

KORKMAZ, Ramazan, Yeni Türk Edebiyatı El Kitabı 1839-2000, Grafiker Yay., Ankara, 2009.

MORAN, Berna, Türk Edebiyatına Eleştirel Bir Bakış 2/ Sabahattin Ali'den Yusuf Atılgan'a, İletişim Yay., İstanbul, 1994.

OLlMAN, Bertell, Yabancılaşma/ Marx’ın Kapitalist Toplumdaki Insan Arayışı, Yordam Kitap, İstanbul, 2008.

PAPPENHEIM, Fritz, Modern Insanın Yabancılaşması, Phoenix Yay., Ankara, 2002.

TABANOĞLU, Cüneyt, Yabancılaşma Kavramı ve Türk Edebiyatında Yabancılaşma, Hacettepe Üniversitesi, Edebiyat Fakültesi, Türk Dili ve Edebiyatı Bölümü, Ankara. (Yayınlanmamış Lisans Ödevi).

ÜNALDI, Halime, Türk Romanı ve Yabancılaşma: Bir Edebiyat Sosyolojisi Denemesi, Selçuk Üniversitesi, Sosyal Bilimler Enstitüsü Sosyoloji Ana Bilim Dalı, Yüksek Lisans Tezi, Konya, 2011. 